\title{
新しい日本学術会議 への期待
}

遠藤實

\section{はじめに}

日本学術会議は2005年10月、新しい体制の下 で第20期が発足した。改革された日本学術会議 の今後の活動には大いに期待している。

私は第 17 期・18期と日本学術会議会員を務め たが、ちょうど第 17 期が始まって間もなく、 1997年12月に行政改革会議の最終報告におい て、当時総理府所属であった日本学術会議は 「当面総務省に存置することとするが、今後その 在り方について、総合科学技術会議で検討する」 こととされた。検討次第によっては、日本学術 会議が消滅しかねない危機が訪れたのである。 そうした情勢の中で、日本学術会議では第 17 期・18期と吉川会長の下で改革についての真剣 な議論が行われ、その改革の方向が総合科学技 術会議での検討にも反映されて、法律改正、新 体制の日本学術会議の発足に到った。その改革 の議論の過程に拁いて、私は第18期に当時の第 7部を代表して「日本学術会議の在り方に関する 委員会」「日本学術会議改革推進委員会」に参画 したこともあって、第19期に黒川会長から「日 本学術会議の新しい体制の在り方に関する懇談 会」の座長を委嘱された。懇談会の目的は、改 革の法改正の精神を踏まえて第20期会員各位が できるだけ速やかに活発な活動に入れるよう、 新しい体制の具体化の在り方、組織・運営等に ついての提案をとりまとめることであった。
ここでは10回に及ぶ恳談会において、改革の 方向を確認しつつ議論したいくつかの基本的な 考え方をご紹介してみたい。

\section{個人的な意識改革の軌跡}

本題に入る前に、私自身の日本学術会議につ いての認識がどのように変化していったかにつ いて述べておきたい。あるいはご参考になるか も知れないと思われるからである。

私と日本学術会議との関わりは1985年に第13 期薬理学研究連絡委員会 (以下、研連) 委員に 任命されたのが始まりで、以来断続的に 20 年ほ どになる。当時、薬理学研連は「国立創薬科学 研究所 (仮称)」の設立を目指して、日本学術会 議から勧告を出して貪おうと努力していた。薬 学系3研連との合同の作業であったが、それは第 13期では実らず、第14期の1990年に、形を変え て提案した「創薬基礎科学の推進について」と いう勧告として実現され、喜んだものである。 しかし、この勧告を具体的成果に結びつける 我々の努力が充分でなく、勧告の効果は現在必 ずしも満足できるものにはなっていない。この 事実を顧みても、個別分野の推進はそれぞれの 分野に属する者の仕事であって、それを後押し するのは、日本学術会議の本来の仕事ではない ことを学びとることができるが、当時の私には そのことが全く分かっていなかった。

そのような次第で、1997年7月、第17期会員 
として初めて任命式に出席したときの私は、日 本学術会議が何をするところか、明確な意識は 何も持ち合わせていなかった。何かをしようと 思って会員に立候補したわけではなく、学会が 推薦してくれたので受動的に引き受けたような 次第でもあった。会員としての自分に課せられ た任務としては、上記の勧告実現への努力と同 じ発想で、日本学術会議の力を借りて自分の属 する個別研究環境の整備に努力することではな いか、というようなことを考えていた。任命式 の後の懇親会で、第13期から三期連続で会長の 大任を果たされた近藤次郎先生が挨拶の中で 「学術会議というのは何をするところか良く分か らないけれども‥」と圥談っぽく言われた言葉 が、強く印象に残っているが、本当に「何をす るところか分からない」組織で、もしも会員が すべて私のような意識しか持っていなかったら、 日本学術会議は行革の波に飲及込まれて消滅し ても仕方がなかったであろう。

\section{科学者総体を代表する学術会議}

第17・18期の吉川会長の下での改革の議論に よって私の意識もすっかり改革された。

日本学術会議会員は旧制度下では、各学術領 域の代表として選ばれていた。しかし、各領域 の代表がそれぞれ自分の個別領域の発展だけし か考えないのであれば、会員間の利害が対立し て、不毛な議論をするだけの結果に終わってし まいかねない。そうではなくて、各領域の代表 がなすべきことは、近縁領域との間や国際的な 連携などを通じて当該領域の学術の発展に努め
る一方、それ以上に、科学の全領域が作る構造 を理解し、科学全体のことを考えることである。

とくに現代の社会は、近年の科学の著しい進 歩の結果、あらゆる場面で科学抜きには考えら れなくなっている。しかもそこには多くの場合、 科学の個別領域よりも科学総体の成果が深く関 わっている。科学は著しい利便を人間社会にも たらし、またもたらしつつある。そして、「理科 離れ」などと言われる一方で、社会は科学者に 対して大きな期待感を抱いている。しかし、利 便性の裏には常に負の効果が潜在的、顕在的に 伴っている。そのような負の側面を解決するの は、当然、科学者総体の社会的責任であり、ま た、科学者総体の連携協力なしには不可能であ る。その科学者総体を代表するのが日本学術会 議である。

ここに日本学術会議の大きな使命がある。日 本学術会議は、疑いもなく学術の全領域に関す る問題、領域間にまたがる問題を中心に、学術 自体の問題に加えて、学術の産み出した社会の 諸問題に対してすべての英知を結集して取り組 むことを主とすべきであり、それこそが全学術 領域の代表で構成される日本学術会議だからこ そできる、そして日本学術会議でなければでき ない仕事である。

こう考えてみれば、私が最初に頭に浮かべて いた自らの特定研究領域の推進への努力などは、 日本学術会議の仕事としては、それが学術全体 の進展にとって重要である場合にのみ取り上げ るべきものであることは明瞭である。 


\section{改革の方向}

レベルの低い私自身の当初の意識とは違って、 実際には日本学術会議はこれまで多くの領域の 英知を集めて、しっかりした問題提起や提言を 数多く行ってきた。ただしその一部は、社会で 大きな問題になってから、いわば後追いの形で 取り上げた場合もある。また一方で過去には、 「大型陳情機関」と挪揄されたように、個別研究 領域の推進に関する「钊告」を「乱発」してき たことも事実である。さらに、せっかく立派な 問題提起や提言を行っても、それを積極的に広 報し、社会に広く知って鿓㧍うという努力が不 足していた。また、私がかつてそうであったよ うに、多くの会員が必ずしも日本学術会議の活 動についての明確な意識を持っていなかったこ とも、日本学術会議が全体としてその存在を世 にアピールする力を弱くしていたと思う。その ようなことのために日本学術会議は、いわば顔 が見えない、「何をするところかわからない」存 在と見えていたのではなからうか。

このような反省から、改革の方向としては、 個別領域の「陳情」は基本的にやめること、学 術の本来有する先見性をもって（後追いでなく） 機動的に、社会における問題に取り組み、中立 的な学術の立場から政策提言を行うこと、そし て広報を充実して社会に対して強力にその成果 を発信すること、それに加えて、何よりも日本 学術会議会員すべてが目的意識をしっかりと持 って活動に参画することである、ということが 見えてくる。

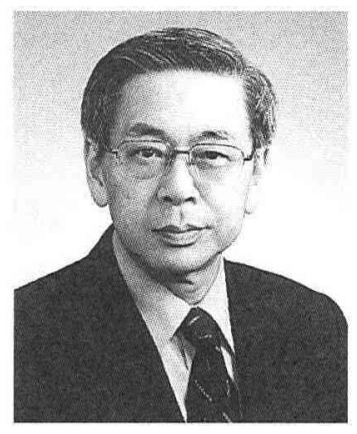

\section{PROFILE}

遠藤 實

(えんどう まこと 1933年生) 第17・18期日本学術会議会員、 第19期「日本学術会議の新しい体 制の在り方に関する愁談会」座 長、埼玉医科大学特任教授、東 京大学・東北大学名誉教授 専門：生理科学、薬理学

\section{総合、国際、長期展望}

日本学術会議がその機能を果たすに当たって、 その特幑をキー・ワードとしてあげれば、総合、 国際、長期展望の三つがあると思う。

日本学術会議はその発足当初から、数学や自 然科学だけでなく、人文科学、社会科学を包含 して構成されてきた。これは欧米のアカデミー には見られない特徵である。先にも述べたよう に現代社会における諸問題は、何を取り上げて も多種多様な要因が複雑に絡まって関係してい るので、その解析や解決に当たっては、科学の 個別領域犬゙けでは处理が不可能で、人文科学、 社会科学を含めた科学が総体として取り組まな ければならない課題ばかりである。そう考えれ ば、日本学術会議の総合力、問題を俯㒈的に捉 えて総合的な解決策を提案する力、がまさに期 待されており、日本学術会議はそれに応えて行 かなければならないことは明らかであろう。

さらに、現代の問題は、地球温暖化を例にあ げるまでもなく、ほとんどが地球规模での問題、 あるいは世界に共通した課題である。その解決 に当たっては、全世界の科学者が連帯して事に 当たらなけ机ばならないが、その際の日本代表 は日本学術会議を扣いて他にない。实際、日本 
学術会議はとくにここ数年、国際科学会議 (ICSU) やInter Academy Council、アジア学 術会議などにおいて中核的メンバーとして力強 い活動を行ってきた。個別領域の学術の進展に 必須の純学術的な国際交流活動を含めた国際交 流、国際協力活動は、日本学術会議の果たすべ きもつとも重要な機能の一つである。

日本学術会議と総合科学技術会議とを対比し て考えると、後者は日本の科学技術政策の決定 に直接深く関わっているが、その視点は予算編 成との関係もあり、どうしても短期的にならざ るを得ない。実際、科学技術基本計画において、 「中長期的」という言葉はせいぜい5年程度の期 間に対して用いられている。他方、科学技術政 策に限ったことではないが、もっともっと長期 的な展望を持って将来の方向を見定め、物事を 決めていかなければならないことは言うまでも ない。継続性が強化された日本学術会議は、そ れをなし得る構造を有して打り、先見性を持っ て長期展望に基づいた提言をしていく責務を有 している。

\section{連携会員}

科学が総体として関わっている現代の諸問題 に取り組むには、全領域、全世界の科学者の連 携、協力が必要である。わが国科学者の総体、 科学者コミュニティーを代表して日本学術会議 が事に当たるためには、たった 210 人の会員で は、とてもその仕事をやり遂げることはできな い。わが国のスケールでは、少なくとも 2,000 人 程度の力が必要であろう。
科学者の代表を選ぶには、どのような基準で 選ぶのが望ましいであろうか？当然のことなが ら、まず学術的に優れた人が代表であるのが相 応しい。優れた仕事を成し遂げた人は、対象を よく観察、分析し、本質を掴み、問題を解決す る力と熱意に満ちているはずである。また、社 会もそのような人には敬意を払い、その言に耳 を傾けるであろう。しかし、学術的に優れた人 達が果たしてすべて現代社会の諸問題に取り組 むのに適しているか、あるいはその意欲を持っ てくれるか、と言えば、必ずしもそうとは限ら ないであろう。けれども、そのような学術的に 優れた科学者のうち、少なくとも1割くらいの人 達は、そうした問題に意欲を持って積極的に取 り組んでくれる人がいるであろう。したがって、 たとえば 2,000 人程度の優れた科学者集団、現代 の日本の科学を代表する人々の集団が日本学術 会議を構成し、そのうちの1割ほどのメンバーが 執行部として積極的に活動するというのがある べき理想の姿ではないか。これが、第18期の吉 川会長の下での改革の議論においての合意であ つた。

現実の日本学術会議法においては、上述の母 集団に相当するものが「連携会員」と規定され ている。したがって、我々の懇談会は、連携会 員は会員と等位かつ一体となって日本学術会議 の機能を果たすものとし、また、連携会員は新 会員及び新連携会員の選考に当たって会員と同 等の推薦権を持つことを提案した。会員は法律 で定年70歳、再任不可とされているが、連携会 員は必ずしも70歳定年制をとらず、再任も2回 
までできることとしたのも、会員は母集団であ る連携会員の執行部的存在であることを意識し たものである。

\section{機動性、柔軟性}

日本学術会議がその機能を充分果たすために は、その組織、運営は機動性を持ち、いろいろ な状況に柔軟に対応できるものでなければなら ない。そのために懇談会では従来の日本学術会 議にはなかったいくつかの運営方式を提案した。 以下にその主要な二、三を記しておく。

総会は原則年2回しか開催されないので、法律 等に規定されている事項以外はすべて幹事会で 議決できることとする。

従来の特別委員会は、期の初めに設置され3年 間審議を行うのが通例であったが、折々の社会 の課題に対応して機動的に委員会を設置し、で きるだけ短期間で結論を出して任を終える。委 員の人選に際しては必ずしも各部均一ではなく 特定分野の者を中心にすることがあっても良い し、会員や連携会員以外に必要な専門家がいれ ばそうした人材にも委嘱するのが良い（そのた めには、学術研究団体から常時人材情報を得て おくことが必須である)。

従来の常置委員会で継続的に議論してきたこ とも、課題ごとに臨時委員会を設置して一つず つ課題を処理して行くこととし、常置の機能別 委員会の設置は必要最小限にとどめる。

\section{おわりに}

日本学術会議の任務は、極めて重要である。
しかし、その仕事が大切なことは分かっていて も、本務の忙しさに追われて、必ずしも思うよ うな活動ができない、という会員、連携会員も 多いことと思われる。

そのためには、事務局の調査分析機能の強化、 外部の調查機関に支援を求めることのできる財 政的基盤強化などが必須である。それが徐々に 充実されて、科学者コミュニティーの代表とし ての日本学術会議の活動が活発になることを心 から期待している。 